\title{
ECCLESIASTICAL
} LAW JOURNAL

\author{
January 2002
}

Discipline of the Clergy: Medieval and Modern

Professor Richard Hi Inihol,

Living in Suspense: Problems and Solutions with Suspension of the Right of Presentation

The Rerd Jonathan Redicrs / Iarris

Diversity in Unity: Approaches to Church Order in Rome and in Byzantium

Futher Clarence Guliagher

\section{Canon Law and Communion}

Professor . Vorman Dre

(For full list of contents, see back cover)

The Journ.al of the Ecclesiastical Law Society 


\title{
ECCLESIASTICAL LAW JOURNAL
}

\author{
EDITORIAL COMMITTEE \\ Michael Goodman (Chairman)* \\ James Behrens \\ Timothy Briden \\ Rupert Bursell \\ Norman Doe \\ David Harte \\ Mark Hill \\ Hughie Jones \\ Lynne Leeder \\ Peter Moore \\ Michael O'Connor \\ Thomas Watkin \\ * Until 1st February 2002 when he is succeeded by Mark Hill
}

\section{EDITORIAL ADVISORY BOARD}

Professor John Baker

Bishop Eric Kemp

Professor Richard Helmholz

Professor Francis Lyall
Chancellor David McClean

Revd Dr Robert Ombres OP

Professor Dr Gerhard Robbers

The Ecclesiastical Law Journal is published by the Ecclesiastical Law Society. Decisions on the publication of individual articles are at the discretion of the Editor but are normally made on the advice of referees, chosen by the Editor as expert in the relevant area. General policies of the Journal are developed in consultation with the Editorial Committee and the Editorial Advisory Board.

The views expressed in any article. review or other publication in this Journal do not necessarily accord with those of the Editorial Committee or the Society as a whole.

Editor

\section{ISSN 0956-618X}

\section{Items in this issue should be cited \\ 6 Ecc LJ}

Typeset in Times Roman on Apple Macintosh and printed by Oxuniprint. Oxford University Press. Great Clarendon Street. Oxford O\.2 6DP.

All rights in this publication are reserved. It may not be reproduced or transmitted in whole or in part, for sale or otherwise. in any form or by any means. electronic or mechanical. including photocopying. recording or storage in any retrieval system, without written permission from the Ecclesiastical Law Society.

\footnotetext{
c The Ecclesiastical Law Society 2002
} 


\title{
ECCLESIASTICAL LAW SOCIETY
}

\section{Patrons}

The Most Revd and Rt Hon the Lord Archbishop of Canterbury

The Most Revd and Rt Hon the Lord Archbishop of York

\section{Vice-Patrons}

The Most Revd the Lord Archbishop of Wales

The Most Revd the Lord Archbishop of Armagh

The Most Revd the Primus of Scotland

\section{President}

The Rt Revd Dr Eric Kemp

Elective Officers (to 2002)

CHAIRMAN: Dr Frank Robson OBE $\dagger$

VICE-CHAIRMAN: The Rt Revd the Lord Bishop of Staffordt

SECRETARY: Peter Beesleyi

DEPUTY SECRETARY: Nicholas J. Richens ${ }^{\dagger}$

TREASURER: The Revd Canon John Reest

\section{Executive Officer}

The Revd Canon Michael O'Connor'

\section{General Committee 2001-2002}

The Officers together with:

\author{
ELECTED: James Behrens (to 2002) \\ The Worshipful Chancellor John Holden (to 2002) \\ The Worshipful Chancellor Charles Mynors (to 2002) \\ The Revd Dr Robert Ombres OP (to 2002) \\ Dr Brian Hanson CBE (to 2003) \\ David Harte (to 2003) \\ The Ven the Archdeacon of Malmesbury (to 2003) \\ Augur Pearce (to 2003) \\ Paul Barber (to 2004) \\ The Revd and Worshipful Chancellor Rupert Bursell QC $\dagger$ \\ (to 2004) \\ The Worshipful Chancellor Michael Goodmant* (to 2004) \\ The Worshipful Chancellor Mark Hill† (to 2004) \\ CO-OPTED: Dr Norman Doe \\ The Worshipful Chancellor Thomas Coningsby QC (to 2002) \\ His Honour Quentin Edwards QC (to 2002)
}

† Member of Executive Committee * Chairman of the Editorial Committee

Web site: www.ecclawsoc.org.uk 